\title{
SUBURBANISATION IN POLAND
}

\author{
Waldemar Łupiński
}

\begin{abstract}
The phenomena of suburbanization are listed in Poland since the midnineties of $X X^{\text {th }}$ century. Their indicators are demographic changes in the structure of resident population and spatial changes in rural areas. Intense divisions of agricultural property for building purposes resulted in significant changes to landscape values of non-urban areas, mainly in the vicinity of major urban centers. In this article were presented the main data relating to demographic changes and changes in the structure of owning and transformation of using grounds, caused by suburbanization processes. There were given practical examples, from the district of Bialystok, in the north - east end of Poland.
\end{abstract}

Keywords: real estate management, suburbanization, Poland, urban areas

\section{Introduction}

Medieval and later design assumptions of castles and settlements, created on Polish territory, had usually focused and compact nature. They were determined mainly by considerations of defense and other functions as: power centers, science and culture, craft, processing, religious and trade centers. The area of the castle or the village - was surrounded by defensive fortifications, defining a spatial framework for the resort. With the development of the industry, which in the Polish lands was marked by the end of the eighteenth century, and developed in the nineteenth and twentieth centuries - were the processes of urbanization. These processes consisted to "spillage" cities in larger areas of more intensive population.

Political changes initiated in 1989, brought a lot of changes in the areas of economic and social live. Among these changes, there were a large freedom in the division of arable plots, trade of them and investment processes, especially in the construction of single-family residential houses. Recovery in the real estate market in this area, mainly related to rural areas, was founded in the mid-nineties the twentieth century and resulted in a progressive phenomenon of suburbanization (Nawrot, 2011). Favored to this situation inconsistent law regulation and the interests of local authorities at the commune level.

The main indicators of a mass character of these processes, in the country level, are statistical changes of urban and rural population. In the local scale, we can notice spatial changes in area of owning and using grounds. 


\section{Demographic symptoms of suburbanization}

In the $30^{\text {th }}$ of September 1921 population of the Republic of Poland consisted 27,177 million inhabitants (24,6\% in urban and 27,4\% in rural areas). In the $31^{\text {st }}$ of December 1938 it was 34,849 million inhabitants (30\% in urban and $70 \%$ in rural areas). According to census from the 1946 year, proportions between urban and rural population were similar (31,8\% to $68,2 \%)$, but population decreased to 23,895 million of inhabitants. In the table (Table 1), we can see slowly process of rebuilt our population (35 years it took to handle the level of population, which was before the II $^{\text {nd }}$ World War), with simultaneous reconstruction in the structure of urban and rural inhabitants (Table 2). Construction of large industrial plants and attempts to collectivization in agricultural areas, conducive to these processes. Turn of the century XX and XXI, brought a change in this trend. We can notice decreasing of population in urban areas, more increase in rural areas, and during the years 2011 and 2012, declining population in the country (negative natural increase).

Table 1: Population balance in Poland, the years 1946 - 2012

\begin{tabular}{|c|c|c|c|c|c|c|c|c|c|c|}
\hline \multirow{2}{*}{ Specification } & $\mathbf{1 9 4 6}$ & $\mathbf{1 9 5 0}$ & $\mathbf{1 9 6 0}$ & $\mathbf{1 9 7 0}$ & $\mathbf{1 9 8 0}$ & $\mathbf{1 9 9 0}$ & $\mathbf{2 0 0 0}$ & $\mathbf{2 0 0 5}$ & $\mathbf{2 0 1 2}$ \\
\cline { 2 - 10 } & \multicolumn{10}{|c|}{ in thous. } \\
\hline Urban areas & 7602 & 9243 & 14401 & 17088 & 20979 & 23546 & 23670 & 23424 & 23336 \\
\hline Rural areas & 16293 & 15792 & 15394 & 15570 & 14756 & 14527 & 14584 & 14733 & 15197 \\
\hline Total & 23895 & 25035 & 29795 & 32658 & 35735 & 38073 & 38254 & 38157 & 38533 \\
\hline
\end{tabular}

Source: Statistical Yearbook (Rocznik, 2013)

Table 2: Percentage of population in urban and rural areas in Poland, the years $1946-2012$

\begin{tabular}{|c|c|c|c|c|c|c|c|c|c|c|}
\hline \multirow{2}{*}{ Specification } & 1946 & 1950 & 1960 & $\mathbf{1 9 7 0}$ & $\mathbf{1 9 8 0}$ & $\mathbf{1 9 9 0}$ & $\mathbf{2 0 0 0}$ & $\mathbf{2 0 0 5}$ & $\mathbf{2 0 1 2}$ \\
\cline { 2 - 9 } & \multicolumn{9}{|c|}{ in \% } \\
\hline Urban areas & 31,8 & 36,9 & 48,3 & 52,3 & 58,7 & 61,8 & 61,9 & 61,4 & 60,6 \\
\hline Rural areas & 68,2 & 63,1 & 51,7 & 47,7 & 41,3 & 38,2 & 38,1 & 38,6 & 39,4 \\
\hline
\end{tabular}

Source: Statistical Yearbook (Rocznik, 2013)

In the Table 3 we can see, that small urban centers, down to 50000 inhabitants, grow up their population, but largest cities were in the process of depopulating. It was concerned mainly of major cities, up to 200 thousands of inhabitants, who have lost their 2,3\% of population.

Significant population growth occurred in the municipalities of 10000 and more inhabitants (Table 4). Usually its areas are adjacent to the major urban centers, and traditionally play the role of "satellite space". They are usually equipped in underground utilities (water, sewerage, gas pipes etc.), and have a good road connection with "major city", too. 
Table 3: Towns and urban population, the years 2000 - 2012

\begin{tabular}{|c|c|c|c|c|c|c|c|}
\hline \multirow{3}{*}{$\begin{array}{l}\text { Groups of } \\
\text { towns by } \\
\text { number of } \\
\text { population }\end{array}$} & \multirow{3}{*}{$\begin{array}{c}\text { number } \\
\text { of towns } \\
\text { in } 2012\end{array}$} & 2000 & 2005 & 2010 & 2012 & 2000 & 2012 \\
\hline & & \multicolumn{6}{|c|}{ urban population } \\
\hline & & \multicolumn{4}{|c|}{ in thous. } & \multicolumn{2}{|c|}{$\begin{array}{c}\text { in \% of total } \\
\text { population }\end{array}$} \\
\hline Below 5000 & 318 & 903,5 & 914,1 & 967,7 & 973,7 & 2,4 & 2,5 \\
\hline 5000-9999 & 181 & 1311,3 & 1338,3 & 1331,5 & 1286,3 & 3,4 & 3,3 \\
\hline $\begin{array}{c}10000- \\
19999\end{array}$ & 186 & 2679,8 & 2663,7 & 2706,6 & 2705,7 & 7,0 & 7,0 \\
\hline $\begin{array}{c}20000- \\
49999\end{array}$ & 136 & 4118,3 & 4157,7 & 4250,6 & 4256,9 & 10,7 & 11,0 \\
\hline $\begin{array}{l}50000- \\
99999\end{array}$ & 48 & 3235,0 & 3290,4 & 3260,5 & 3240,7 & 8,5 & 8,4 \\
\hline $\begin{array}{l}100000- \\
199999\end{array}$ & 22 & 3118,9 & 3065,7 & 3014,3 & 2996,1 & 8,2 & 7,8 \\
\hline $\begin{array}{l}200000 \text { and } \\
\text { more }\end{array}$ & 17 & 8303,5 & 7993,8 & 7897,9 & 7876,8 & 21,7 & 20,4 \\
\hline Total & 908 & 23670,3 & 23423,7 & 23429,1 & 23336,4 & 61,9 & 60,6 \\
\hline
\end{tabular}

Source: Statistical Yearbook (Rocznik, 2008), (Rocznik, 2013)

Table 4: Gminas and rural population, the years 2000 - 2012

\begin{tabular}{|c|c|c|c|c|c|c|c|}
\hline \multirow{3}{*}{$\begin{array}{l}\text { Groups of } \\
\text { towns by } \\
\text { number of } \\
\text { population }\end{array}$} & \multirow{3}{*}{$\begin{array}{l}\text { number } \\
\text { of } \\
\text { gminas } \\
\text { in } 2012\end{array}$} & 2000 & 2005 & 2010 & 2012 & 2000 & 2012 \\
\hline & & \multicolumn{6}{|c|}{ rural population } \\
\hline & & \multicolumn{4}{|c|}{ in thous. } & \multicolumn{2}{|c|}{$\begin{array}{l}\text { in \% of total } \\
\text { population }\end{array}$} \\
\hline Below 2000 & 30 & 34,7 & 43,4 & 46,6 & 45,6 & 0,1 & 0,1 \\
\hline 2000-4999 & 746 & 2876,5 & 2854,2 & 2904,0 & 2866,4 & 7,5 & 7,4 \\
\hline 5000-6999 & 570 & 3666,9 & 3594,8 & 3434,4 & 3391,1 & 9,6 & 8,8 \\
\hline 7000-9999 & 452 & 4101,5 & 3931,3 & 3727,8 & 3749,1 & 10,7 & 9,7 \\
\hline $\begin{array}{l}10000 \text { and } \\
\text { more }\end{array}$ & 375 & 3904,1 & 4309,7 & 4822,8 & 5144,6 & 10,2 & 13,2 \\
\hline Total & 2173 & 14583,7 & 14733,4 & 14935,6 & 15196,9 & 38,1 & 39,4 \\
\hline
\end{tabular}

Source: Statistical Yearbook (Rocznik, 2008), (Rocznik, 2013)

\section{Extent of the phenomenon of the "new settlement"}

Down strict limits suburbanisation phenomena is an impossible task. On the one hand, due to the "disorder" of existing ships in the vicinity of larger towns small towns, which are of the strong influence of the impact of an urban center, on the other hand, that same these centers also generate processes of suburbanization. 
It can be assumed that the impact of an urban center on the processes of the "new settlements" have a radius of about $50 \mathrm{~km}$. Support this communication issues: widespread transport of persons, organized communication collective (bus or train), and recently built a bicycle paths. Travel time to a larger urban center, using a car, bus or train, should not be longer than one hour, because it is the distance to daily overcome on the way to work, school, community centers, health care, etc.

All the problems associated with the phenomena of suburbanization, appropriate for the Polish, we can observe on the example of the Bialystok district (Map 1).

Map 1: The Bialystok district and its communes, relative to the city of Bialystok

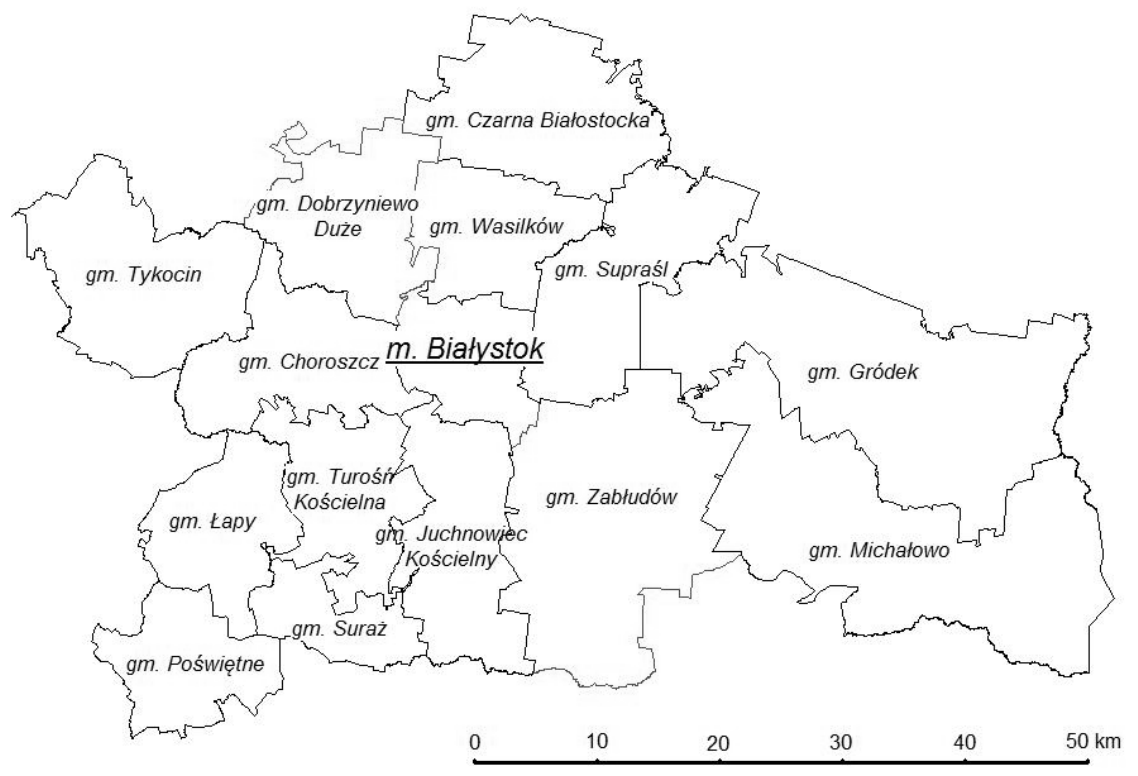

The city of Bialystok has an average value type (295 000 inhabitants) and is a local central city, in the north - east Poland. The nearest towns are Suraż, Łapy, Choroszcz, Tykocin, Wasilków, Czarna Białostocka, Supraśl and Zabłudów. Their population ranges from 1000 residents in Suraż to 16000 residents in Łapy.

\section{Spatial forms of "new settlement"}

Just like every phenomenon, including the processes of suburbanization, after several years of development, may be subject to classification. Observed in the land district of Bialystok "new settlement processes" can be classified as: 
- complement complexes built-up areas of rural settlements;

- complement complexes built-up colonies in rural areas;

- creating new, complex residential areas among of agricultural lands and forests;

- creation of new, single seats among of agricultural land and forests (enclaves).

The first of the presented cases, associated with the "make-up complexes built-up areas of rural settlements" should be considered correct. Complement the existing buildings within the rural settlements in the area of the interior or in the immediate vicinity, adjacent to the existing buildings, is a natural practice, used traditionally in the district of Bialystok. In this case, the "new settler", can take advantage of the available elements within the housing and utilities (access to the paved road, in most cases, it is a asphalt road, less with stone sufrace, access to water supply, sanitary sewer, and sometimes, network access power, a permanent telephone line, in the few settlements is also available gas network). Subsequent cases, introduce far-reaching changes in the rural landscape. Body type colony, creating accordance with the school of land consolidation in the interwar period, had the task of bringing economic center for farm land. Creating residential areas located in the area in colonial type, a challenge to the basic criterion for the existence of functional building type colony. Similar disturbances as landscape, will introduce building housing estates, in areas remote from existing buildings, both in the form of several or a dozen plots, as well as individual construction enclaves surrounded by rural land (agricultural use, though there are also such cases to contact complexes of agricultural and forest). These investments are not at all related to farming, and their appearance introduces dissonance comparable with the assumption of rural economic center in the city center.

\section{Changes in shaping the boundaries of agricultural property}

Localization processes related to the implementation of the "new settlement", are often signs of acts disasters, which are more decision of the previous owner of agricultural property - rather than the result of a deliberate, planned the creation of residential complexes. On (Map 2) and (Map 3), are presented two examples of divisions of land, previously used for agriculture, in order to sell the plots for construction purposes. These are examples of changes in the configuration of the property boundaries, introduced in the name of the particular interests of the owner, without respect for the basic principles of spatial cohesion, the protection of the countryside or the ordinary rules of logic. 
Map 2: The subject of the division, was the plot situated in the central part of the figure. Separated from her 9 plots for construction purposes and the access road. Example comes from village Pańki, municipality Choroszcz

Map 3: Example from village Juchnowiec Dolny, municipality Juchnowiec Kościelny. Parameters "of the plot of the original" allowed the separation by the middle of the access road and "two ladders" of building lots in the number of 39th Separate plots are surrounded by arable land

Map 2

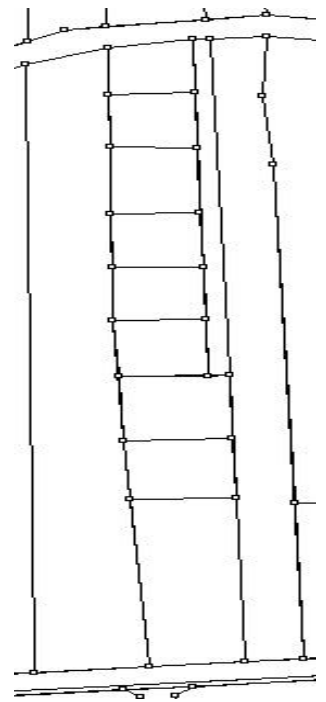

Map 3

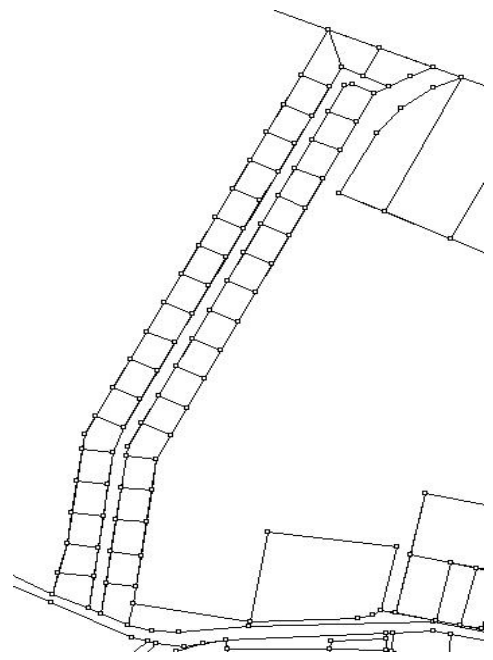

From the technical point of view, these divisions are flawless. Each of the separate parcels have spatial parameters, enabling the realization of the construction in terms of single-family housing. These plots also have access to public road use (from the property, the road is in accordance with the Decision approving the project division, or passes for compensation to the competent local municipality, or is owned by the previous owner, the establishment of the easement passage to separate plots for compensation incriminating owners - buyers separate parcels).

Possession of agricultural land on more favorable spatial parameters can be inspired to create entire compact settlements that are appropriate for urban areas (Map 4) and (Map 5). 
Map 4: Barszczewo village, municipality Choroszcz. Example composition of settlements - enclaves on arable land in the immediate vicinity of the complex of private forests, on the south side

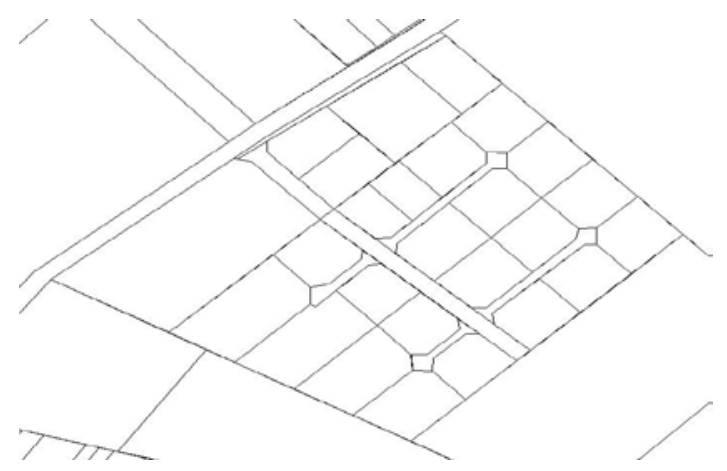

Map 5: Example of a compact housing. Ignatki village, municipality Juchnowiec Kościelny

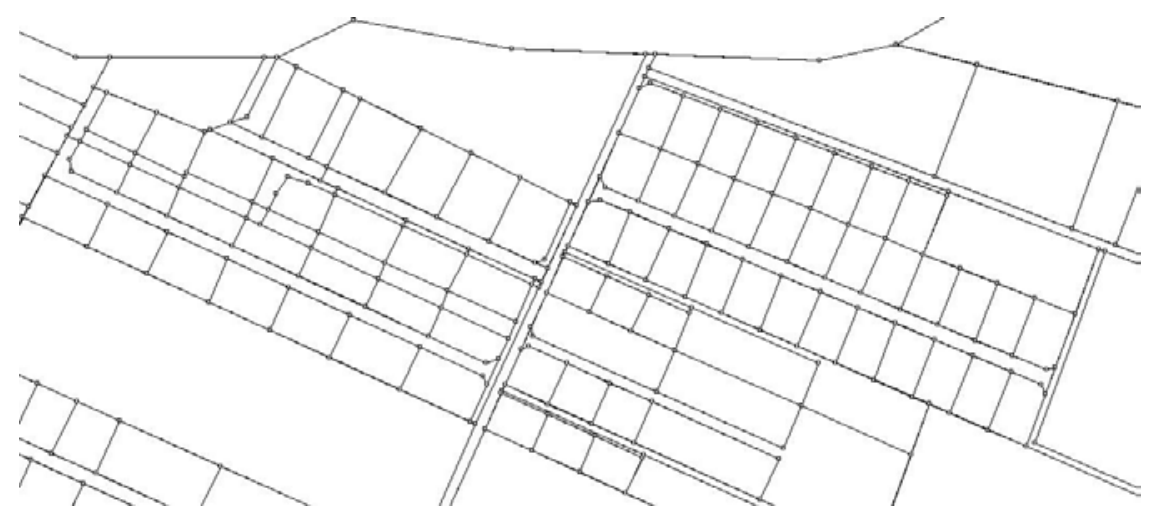

Above, there were presented unit of division of agricultural property, with a view destined for construction purposes (in practice, most of these plots has already found new owners, for many of them were finished realization of buildings, or they are during realizing). The way in which these divisions affect the condition of the entire spatial surveying districts, shown in (Map 6).

Kuriany village is a typical example of spatial changes in owning and using grounds, in the neighborhood of city area. The village has lost its agricultural character, transforming the estate. Planning authority, was not able to organize space in a rational manner, villages directly adjacent to the city, lost their traditional landscape and functional properties. 
Map 6: Village Kuriany, municipality Zabłudów. "Mosaic" location of land for single-family housing. Rural habitats - are located in the western part of the village

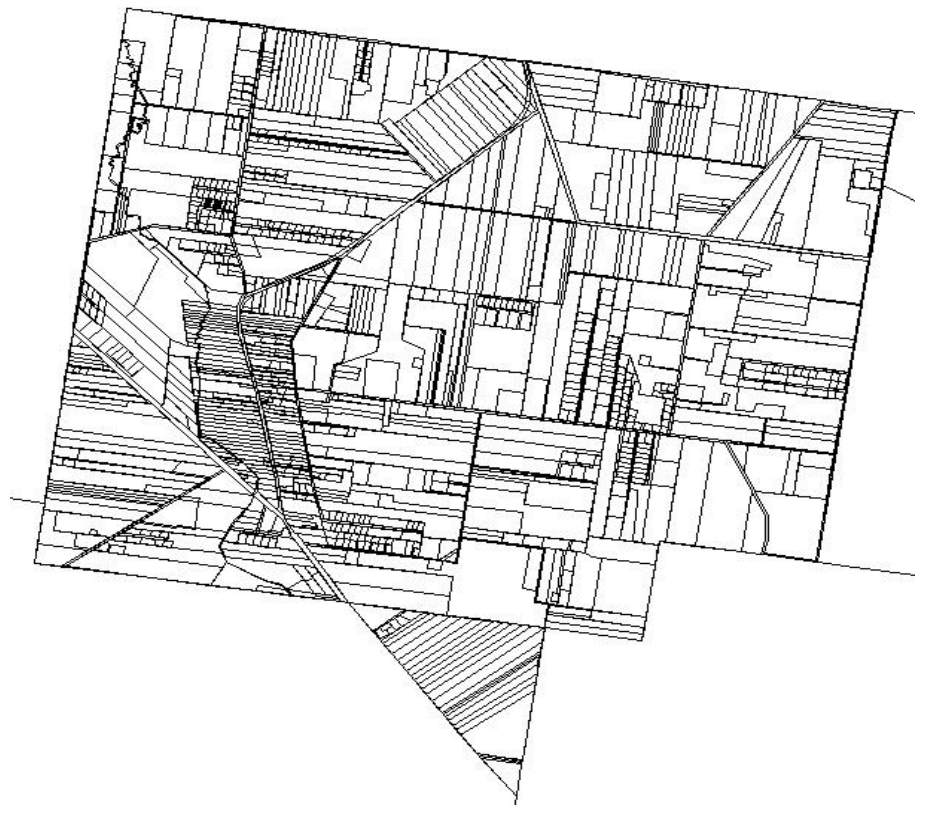

\section{Conclusion}

Presented at work issues are just some of the problems associated with the appearance of the rural areas of the "new settlement". The processes of suburbanization, should be considered a natural stage in the development of spatial forms of using and owning grounds (Nawrot, 2011). The study of progress of these phenomena, facilitate Internet available Geoinformation data (Kowalski, 2008), (Portal białostockiego geoportalu powiatowego, 2014). It is the actual source of information about spatial changes in this area.

Directions of suburbanization development, overtook the reaction of circles related to real estate, and responsible for it. The level of spatial problems and conflicts, has now become a fait accompli. We should expect that the effects of these processes remain a problem for many years. Giving to identify conflicts are:

- differences in land use (particularly disadvantageous for settlements adjacent to agricultural complexes appear to be agricultural practices such as the use of natural and artificial fertilizers, pesticides, etc.);

- variation in the domestic needs of the "new" and "old" inhabitant (supply sewerage, access to the Internet, access to education and universal health care); 
- cultural differences "new settlers" (derived mainly from the cities, there born and educated) and existing residents, resulting in the breakdown of traditional rural communities; and others.

Noticeable has become, in recent years, a slowdown in investment processes in rural areas, in terms of housing. Accompanied by a decline in interest in buying plots in rural areas, and consequently, a decline in their prices. This is brought about by the economic crisis, more difficult to obtain, still very expensive loan, and, in a sense, saturation of the market. Despite these symptoms, it seems unlikely to be a quick revitalization of the rural areas in order to organize the processes of the "new settlement" because many construction projects, it became a fait accompli. Many of them take place in the nearby cities, making it difficult objectives such as improving the technical parameters of roads or construction of new road connections, for example by the form of bypasses (Gawryluk, 2012).

Spatial conflicts arise: business communities, rural development, business existing residents and "new settlers", require special attention. It is necessary to approach the municipality to verify the findings of local development plans and spatial development studs, for more informed decisions in the field of locationfamily housing. In order to secure investment areas in the field of single-family housing, reasonable seems to be the creation of the municipality, compact complexes within the communal land resources, as well as initiating revitalization programs, including areas already covered by the processes of the "new settlement".

\section{Acknowledgements}

The paper was prepareted by project S/WBiIŚ/3/2013 Modelowanie procesów i obiektów w zastosowaniach inżynierskich $i$ w gospodarowaniu przestrzenia.

\section{References}

GAWRYLUK, D. 2012. Budowa obwodnic szansa na odzyskanie rynków przez małe miasta (Ostrów Mazowiecka, Zambrów, Grajewo). Czasopismo Techniczne. Architektura R. 109, z. 3A, Politechnika Krakowska, Kraków, s. 205-209.

KOWALSKI, P. J. 2008. Techniczne aspekty redagowania i użytkowania serwisów geoinformatycznych. Polski Przegląd Kartograficzny T. 40, nr 4, s. 337-348, Warszawa

NAWROT, B. 2011. Obszar metropolitalny jako propozycja zmian w systemie zarządzania lokalnego w Polsce; Wieloaspektowość samorządności gminnej w Polsce, red. Nawrot B., Pokładecki J., Poznań, s. 169 - 186.

PORTAL BIAŁOSTOCKIEGO GEOPORTALU POWIATOWEGO 2014. http://bialystok.geoportal2.pl/map/www/mapa.php 
ROCZNIK STATYSTYCZNY RZECZYPOSPOLITEJ POLSKIEJ 2008. Główny Urząd Statystyczny. Warszawa.

ROCZNIK STATYSTYCZNY RZECZYPOSPOLITEJ POLSKIEJ 2013. Główny Urząd Statystyczny. Warszawa.

Waldemar Lupiński, dr inż.

Zakład Informacji Przestrzennej

Wydział Budownictwa i Inżynierii Środowiska

Politechnika Białostocka

ul. Wiejska 45E, 15-351 Białystok, Polska

E-mail: w.lupinski@pb.edu.pl 